\title{
Including reliability in the AASHTO-93 flexible pavement design method integrating pavement deterioration models
}

\author{
Inclusión de confiabilidad en el método de diseño de pavimentos flexibles AASHTO-93 \\ integrando modelos de deterioro de pavimentos
}

\author{
Mario Alberto Rodríguez Moreno (Main and Corresponding Author) \\ Facultad de Ingeniería, Universidad de Medellín \\ Carrera 87 No 30-65 Medellín (Colombia) \\ marodriguez@udem.edu.co
}

\section{Tomás Echaveguren Navarro}

Facultad de Ingeniería, Departamento de Ingeniería Civil, Universidad de Concepción

Edmundo Larenas 219, Concepción (Chile)

techaveg@udec.cl

\section{Guillermo Thenoux Zeballos}

Escuela de Ingeniería, Pontificia Universidad Católica de Chile

Av. Vicuña Mackenna 4860, Macul, Santiago (Chile)

gthenoux@ing.puc.cl

Manuscript Code: 713

Date of Acceptance/Reception: 30.06.2017/17.11.2015

DOI: $10.7764 /$ RDLC.16.2.284

\begin{abstract}
The reliability used in the pavement design is assigned according to recommendations of design guides or according to the designer's criteria; that is to say, there is no rational tool for their estimation. In addition, the chosen value is deterministic and does not consider the random nature of the process or the actual conditions of load, climate, material behavior and impact of the construction process that affect the performance of the structure when it is in service. This research proposes to link the design method and calibrated deterioration models to local conditions that consider the actual behavior of the materials, the variability of the construction process, the actual load stresses and the weather, when in operation. For this, a Monte Carlo simulation model is developed, using field data and statistical concepts that allow defining the variables of the model as random variables. Subsequently, with the variables found and using the reliability theory and the serviceability model, the design method and the models of deterioration are evaluated through a supply and demand analysis to obtain the reliability value that reduces the uncertainty of the performance of the structure when operating.
\end{abstract}

Key words: Reliability, pavement design, deterioration models, serviceability, pavement design life, pavement service life.

\section{Resumen}

La confiabilidad usada en el diseño de un pavimento se asigna según recomendaciones de guías de diseño o de acuerdo al criterio del diseñador, es decir no existe una herramienta racional para su estimación. Además, el valor elegido es determinista y no considera la naturaleza aleatoria del proceso ni las condiciones reales de carga, clima, comportamiento de materiales e impacto del proceso constructivo que afectan el desempeño de la estructura cuando se encuentra en servicio Esta investigación propone enlazar el método de diseño y los modelos de deterioro calibrados a condiciones locales que consideran el comportamiento real de los materiales, la variabilidad del proceso constructivo, las solicitaciones reales de carga y clima cuando se encuentran en operación. Para ello se desarrolla un modelo de simulación del tipo Monte Carlo, usando datos de campo y conceptos estadísticos que permiten definir las variables del modelo como variables aleatorias. Posteriormente, con las variables encontradas y utilizando la teoría de confiabilidad y el modelo de serviciabilidad, se evalúa el método de diseño y los modelos de deterioro a través de un análisis de oferta y demanda para obtener el valor de confiabilidad que reduce la incertidumbre del desempeño de la estructura cuando se encuentra en operación

The pavement design methods estimate the thickness of pavement layers needed to support the weight of vehicle loads and the weather conditions during its service life. The pavement structural design methods are classified in mechanistic (based on the mechanics of the materials) (Tighe et al., 2007); empirical, (based on laboratory or field tests) (Carvalho \& Schwartz, 2006); and mechanistic-empirical (the pavement structure is designed through a mechanistic analysis, and its performance is assessed through deterioration models to adjust the structure's design) (Carvalho et al., 2006). Whatever the hypothesis of the design method used, reliability is always involved as a way of taking into account the uncertainty of variables such as traffic growth, traffic loads, environmental conditions, damage 
progression, mechanical properties and structural performance of the materials as well as of the quality of the building processes (AASHTO 1993; Sánchez-Silva et al., 2005).

In several Latin American countries, such as Chile (MOP, 2015) and Colombia (INVIAS, 2012), the pavement design is performed by using adaptations of the AASHTO-93 empirical design method. This method estimates the reliability of the design by establishing a confidence level $(R)$ that defines the variance level adopted in the design $(\mathrm{Zr})$ and the variance estimated from each one of the factors used in the prediction of the model (So). The confidence level is estimated based on general recommendations provided by the Guide for Design of Pavement Structures of AASHTO (1993) and eventually according to the experience and criterion of the designer. In other words, there is not a well establish objective tool for estimating the confidence level during the design.

Inputs and outputs of the AASHTO-93 method are deterministic, and they do not take into account the uncertainties in the design, construction and operation. This means that the expected performance of the solution cannot be guaranteed in an absolute sense as in AASHTO-93, but that it should be evaluated in terms of the probability of success to satisfy a performance criterion based on the number of load repetitions (equivalent standard axle load of $80 \mathrm{kN}$ ), which defines the pavement's service life. In these terms, the reliability of the design is understood as "the probability that loads actually applied on the pavement, do not exceed the number of load applications that can be withstood until reaching the minimum serviceability level proposed in the design" (AASHTO, 1993).

For a robust basis of pavement performance over time, pavement deterioration models are needed, which allows predicting the damage, giving tools to recommend the adequate maintenance technique, establishing the allocation of resources, scheduling interventions, projecting the cash flow of the administrator and calculating the final cost and profitability of the project. This can guarantee that the pavement will maintain the serviceability indicators demanded by the highway agency, thereby ensuring that the structure will endure during the operation time specified in the design, optimizing the investment costs (Videla et al., 1996).

Deterioration models are mathematical expressions based on field data, which can be considered as mechanisticempirical, if the pavement condition is related with the stress and strain states of the layers; or empirical when they are obtained from the statistical analysis of deterioration trends observed locally on site and which relate the condition of the pavement with the traffic demand and the weather condition. Both types of models can be developed using tools such as: Bayesian approaches, clusterwise regressions, stochastic models, neural networks, or Markov chains, among others methods. The empirical deterioration models most frequently used in pavement management are those developed by Morosiuk (1999), which evaluate the pavement performance using a deterministic framework. In Chile, Videla et al. (1996) and the Ministry of Public Works (MOP 2010) calibrated asphalt pavement deterioration and de Solminihac et al. (2003) calibrated deterioration models for surface treatments using a deterministic framework as well.

Figure 1 shows a flexible pavement serviceability model of AASHTO-93, where the loss of serviceability occurs throughout the design life for two reliability values ( $85 \%$ and $95 \%$ ). In Figure 1, SN is the structural number, $\mathrm{S}_{0}$ is the standard deviation of the compound error, $P_{i}$ the initial serviceability, Pf the final serviceability and CBR represents the California Beating Ratio. Figure 1 allows establishing that the number of equivalent axles which defines the end of a pavement's design life (according to the final serviceability) inversely depends on the chosen reliability value. In other words: if a design assumes a final serviceability value of 2 and assigns a reliability value of $85 \%$ (blue line), the number of equivalent axles that defines the end of the design life is 4 million, but if a reliability value of $95 \%$ (red line) is used instead, this number will drop to 2 million equivalent axles, that is, $100 \%$ smaller.

Figure 1. Design life variation of a flexible pavement related to the reliability value. Self-prepared.

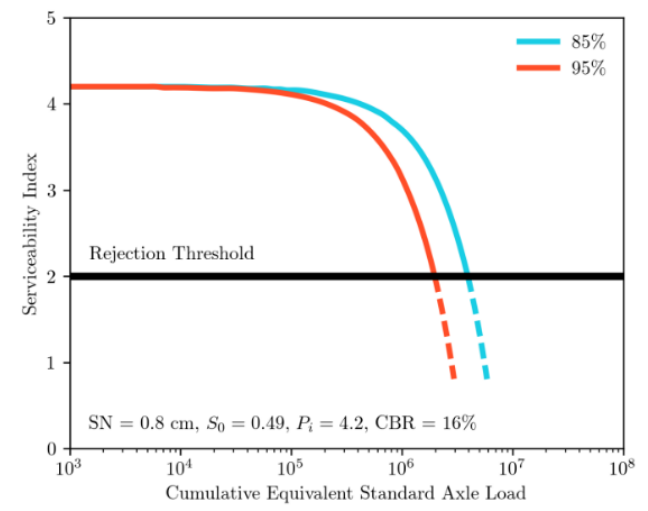


This analysis shows the influence of the reliability value on the pavement design life, demonstrating that a wrong estimate can generate a different performance than the one assumed in the design or, in other words, under- or overdimension the structures.

In conclusion, during the process of defining the reliability value used in structuring the thickness of a pavement there are deficiencies such as: not considering the random nature of the process, simplifying the variables of the model as deterministic values; absence of rational tools that allow establishing the design reliability; uncertainty regarding the behavior of the pavement in service; and the possibility of under- or over-dimensioned structures.

According to the above, the goal of this article is to present an objective procedure based on the reliability theory, to estimate the real reliability of the design, based on the AASHTO-93 design method, and calibrated deterioration models applied to local conditions. To achieve this, the research methodology considers the following steps:

- Development of a simulation model of the Monte Carlo type, using statistical concepts and field data to define input and output variables of the design method and the deterioration model as random variables.

- Using the output variables defined above and concepts of the reliability theory to perform a supply and demand analysis to obtain the reliability value that ensures an adequate behavior of the pavement when in service.

- Developing a case study with roads located in Chile, while applying the proposed procedure to find the reliability value of the design.

Finally, the most important purpose of this research was to use the reliability theory concepts to consider the variability of the procedure and to solve the subjectivity problem in the definition of the reliability value used in the design, by using models of deterioration calibrated to local conditions that allowed reducing the uncertainty of the performance of the structure when it enters into service.

\section{Reliability assessment of the pavement design}

\section{Conceptual framework of the reliability model}

If we consider the variability involved in the pavement design, construction, operation and maintenance, the design life specified by the design method and the service life specified by the deterioration models can be defined as supply and demand, respectively. Both of them present some degree of variability that can be characterized by Probability Density Functions (PDFs). Figure 2 illustrates the variability effect on the pavement performance.

The design life provided by design follows a PDF $f_{R}(r)$ with mean $\mu_{R}$ and variance $\sigma_{R}$. The service life estimated from the deterioration model is represented by a PDF $f_{S}(s)$ with mean $\mu_{s}$ and standard deviation $\sigma s$. Both variables are independent uncorrelated continuous random variables, that is, the variation of one of them does not depend on the value that the other one takes and the covariance among them is zero.

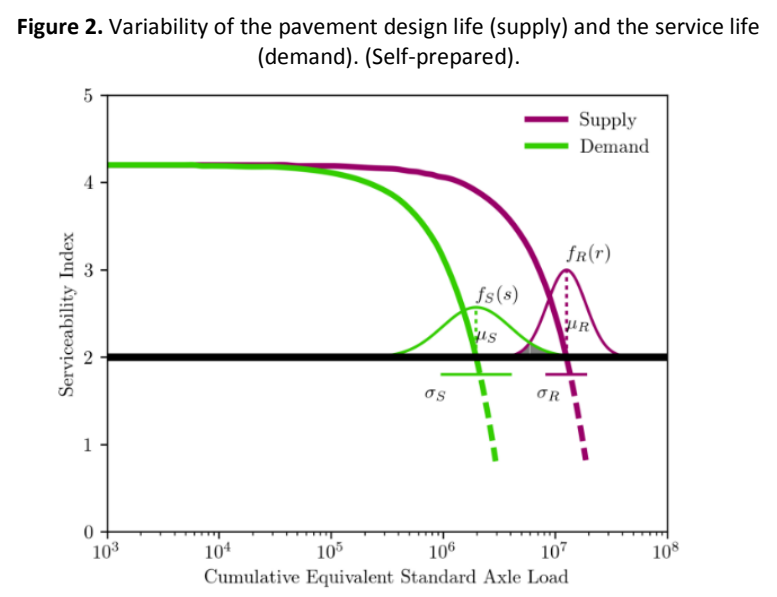

Thus, if $f_{R}(r)$ and $f_{S}(s)$ are PDF that represent supply and demand respectively, then the reliability of the pavement service life is defined with a probability that the supply will exceed the demand, according to Equation 1.

Reliability $=P(R>S)$ 
There is an overlap zone between the PDF of $f_{R}(r)$ and $f_{S}(s)$, which represents the parametric response space where the failure may occur or not; this region is represented by a Performance Function expressed by Equation 2 (Haldar \& Mahadevan, 2000).

$$
Z=R-S
$$

The different values that the Performance Function can take generates two regions within the parametric response space (Haldar \& Mahadevan, 2000). One, where $Z>0$ (successful design), and another where $Z<0$ (failed design). Both regions are delimited by a boundary when $Z=0$, which is called Failure Surface or Limit State Design. It is defined as the state beyond which a pavement structure is not capable of fulfilling the function for which it was designed or the boundary between the safe and the unsafe zone. The region described by $Z=0$ can be linear or nonlinear depending on the specification of $f_{R}(r)$ and $f_{S}(s)$.

The minimum distance from the original coordinates $(S, R)$ is called Reliability Index $b$ and allows localizing, on the Failure Surface, the Point of Design, which is considered the most probable point of failure of the design and represents the worst combination of the basic random variables of Supply $f_{R}(r)$ and Demand $f_{S}(s)$ as a solution of the function $Z=0$. The distance $(B)$ is the system's reliability indicator; if it is far from the coordinate axis, the safe region is bigger and, therefore, the reliability is high. The opposite occurs if there is a short distance from the origin. Since the distance $(B)$ is established as the minimum value generating the failure of the system (with failure probability $P_{f}$ ), we can define the reliability as:

$$
\text { Reliability }=1-P_{f}
$$

The First-Order Reliability Methods (FORM) allows estimating the 8 parameter. It evaluates the function of the limit state when it is a linear function of normally distributed uncorrelated variables, or when the limit state function is non-linear and it is represented by first-order linear approximations of equivalent normal variables. In this case, if the variables are normalized, the so-called Hasofer-Lind reliability index $\left(\beta_{H L}\right)$ can be estimated (Hasofer $\&$ Lind, 1974). If the PDF represented by variables $R$ and $S$ are non-normal, it is necessary to transform it into equivalent normal variables using transformations such as the Rosenblatt's transformation (Rosenblatt, 1952). It allows obtaining statistically independent standard normal variables, if the cumulative distribution function of the variables is known.

The following researches, among others, took into consideration the reliability analysis to find reliability in the design: Luo et al. (2014) developed a reliability-based approach for mechanistic-empirical asphalt pavement design, which reduces the simulation software, considering fatigue and rutting failures through the FORM method. Dilip et al. (2012) developed a probabilistic retro-analysis based on the Bayes Theorem by means of Markov chains, to determine the reliability of a pavement designed by empirical-mechanical methods. The study found that the parameters that contribute to the failure of the structure are the modulus of elasticity of the base layer and the rolling density. Rajbongshi (2014) developed a reliability analysis to find a cost-effective design methodology considering fatigue and rutting failures. Thyagarajan et al. (2011) developed a new technique that reduces the number of simulations to perform reliability analysis in MEPDG. Mun (2014) developed a probabilistic investment analysis tool for structural pavement design to determine design parameters of the pavement performance function in the AASHTO-93 design equation using Monte Carlo simulation and momentum methods. It was found that the structural number significantly affects the pavement performance function.

\section{Specification of the Design Life $f_{R}(r)$}

Figure 3 represents the flowchart of the procedure used to estimate the design life $f_{R}(r)$ based on the AASHTO-93 flexible pavement design guide according to Rodríguez et al. (2016). The output is a set deterministic values of the number of equivalent axle loads of $80 \mathrm{kN}$ cumulated until rising the final serviceability $\left(P_{f}\right)$ obtained by Monte Carlo simulation. In each run, different values of input variables are used (structural number $\mathrm{SN}$, resilient modulus $\mathrm{M}_{\mathrm{R}}$ ). For parameters and constants (initial serviceability $P_{i}$ and final serviceability $P_{f}$ ), the values remain unchanged. In this way, the AASHTO-93 mathematical model provides a set of responses that were tested using the standard likeness of fit test to define the probability density function that characterizes the pavement design life $f_{R}(r)$. 
Figure 3. Flowchart to obtain the basic random variable of design life $\boldsymbol{f}_{\boldsymbol{R}}(\boldsymbol{r})$ (Self-prepared) (See Rodriguez et al, 2016 for details)

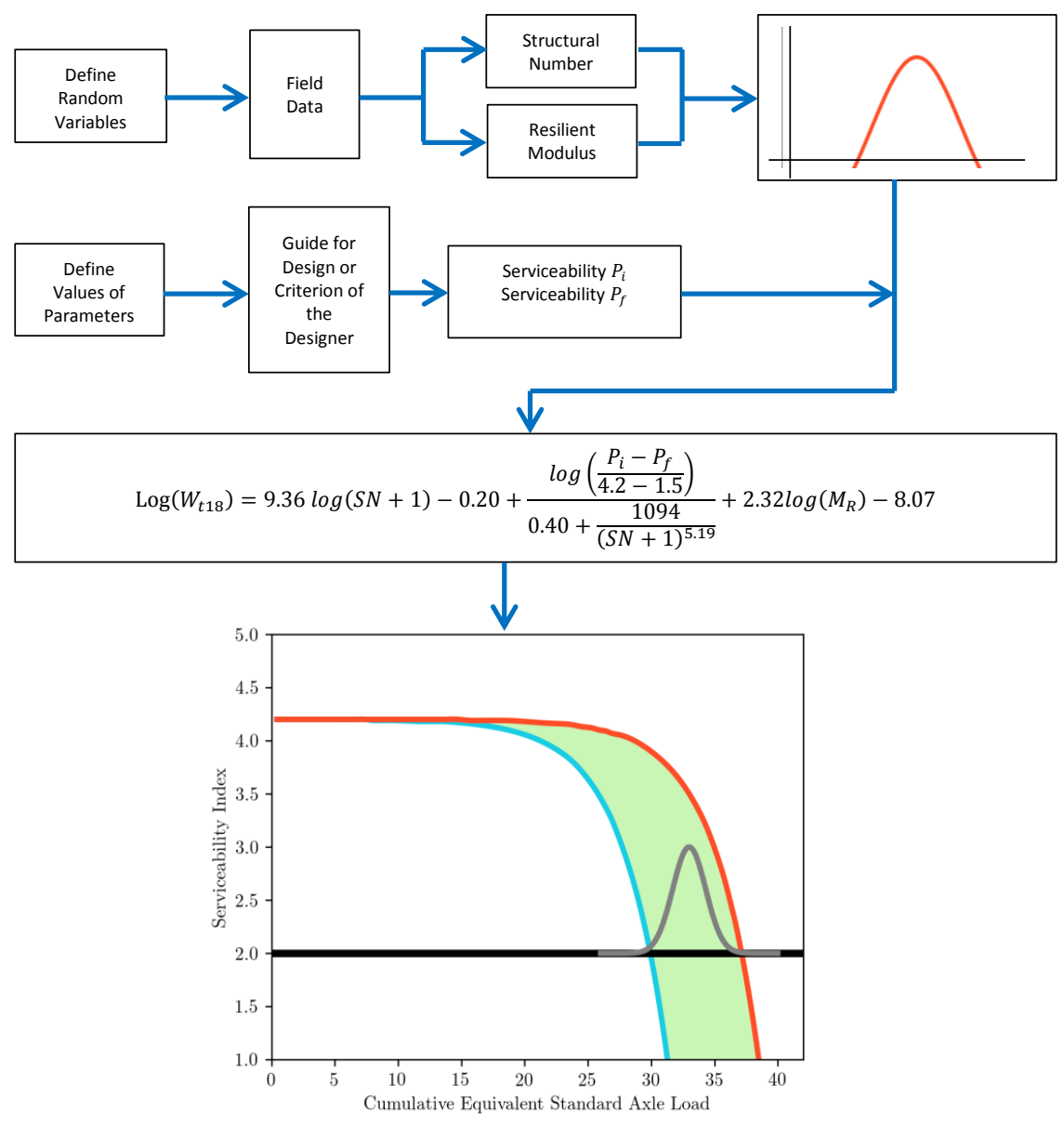

Specification of the Service Life $f_{S}(s)$

Figure 4 shows the flowchart of the procedure used to obtain the design life $f_{S}(s)$. The model is based on the integration of the PSI model of Al-Omari and Darter (1994) and the roughness models of Morosiuk (1999) that, at the same time, depend on the cracking and rutting models developed by Morosiuk (1999). In essence, the procedure used to obtain the service life $f_{S}(\mathrm{~s})$ is similar to that used to obtain the design life $f_{R}(\mathrm{r})$. Repeated execution using different values of the input data were obtained using the Monte Carlo Simulation and the output data were fitted to a PDF.

The probability density function that characterizes the service life $f_{S}(s)$ is defined by the model of Al-Omari and Darter (1994), where PSI is the Present Serviceability Index and IRI is the International Roughness Index in millimeters per kilometer. The PSI is calculated with the model of Equations 4 and 5.

PSI $=5 \mathrm{e}^{(-0.24 \mathrm{IRI})}$

$\Delta \mathrm{RI}=\left\{\Delta \mathrm{RI}_{\mathrm{S}}+\Delta \mathrm{RI}_{\mathrm{C}}+\Delta \mathrm{RI}_{\mathrm{r}}\right\}+\Delta \mathrm{RI}_{\mathrm{e}}$

Where: $\Delta \mathrm{RI}$ is the incremental change of roughness; $\Delta \mathrm{R} \mathrm{Is}_{\mathrm{s}}$ is the structural component of roughness, which considers the deformation of pavement materials because of the traffic loads and it is estimated by Equation $6 ; \Delta R I c$ is the roughness component due to cracking, estimated using Equation $7 ; \Delta R \mathrm{I}_{\mathrm{r}}$ is the rutting component estimated using Equation 8; and $\Delta \mathrm{Rl}_{\mathrm{e}}$ is the environmental component of roughness estimated with Equation 9.

$\Delta \mathrm{RI}_{s}=\mathrm{k}_{g s} a_{0_{g s}} \exp \left(m k_{g m} A G E 3\right)(1+S N)^{-5} Y E 4$

Where $\Delta \mathrm{RI}_{\mathrm{s}}$ is the incremental change of roughness due to the structural deformation during the analysis year (IRI $\mathrm{m} / \mathrm{km}) ; \mathrm{m}$ is the environmental coefficient - parameter; $\mathrm{k}_{\mathrm{gs}}, \mathrm{k}_{\mathrm{gm}}$ are calibration factors for the structural component of roughness; AGE3 is the time elapsed from the last overlay or pavement reconstruction or new reconstruction; $a_{0_{g s}}$ 
is a constant of the structural component of the roughness model; SN is the structural number in inches; and YE4 is the traffic in millions of equivalent axles accumulated by lane.

$\Delta \mathrm{RI}_{\mathrm{C}}=\mathrm{k}_{g c} a_{0 g c} \Delta A C R A$

Where $\triangle A C R A$ is the incremental change of all cracking occurred during the analysis year - input variable (\% of the road's total area); $\mathrm{k}_{\mathrm{gc}}$ is a calibration factor for the component due to cracking; $a_{0_{g c}}$ is a constant of the roughness model's cracking component.

Figure 4. Flowchart to obtain the Probability Density Function of Service Life $\boldsymbol{f}_{S}(\boldsymbol{s})$. (Self-prepared).

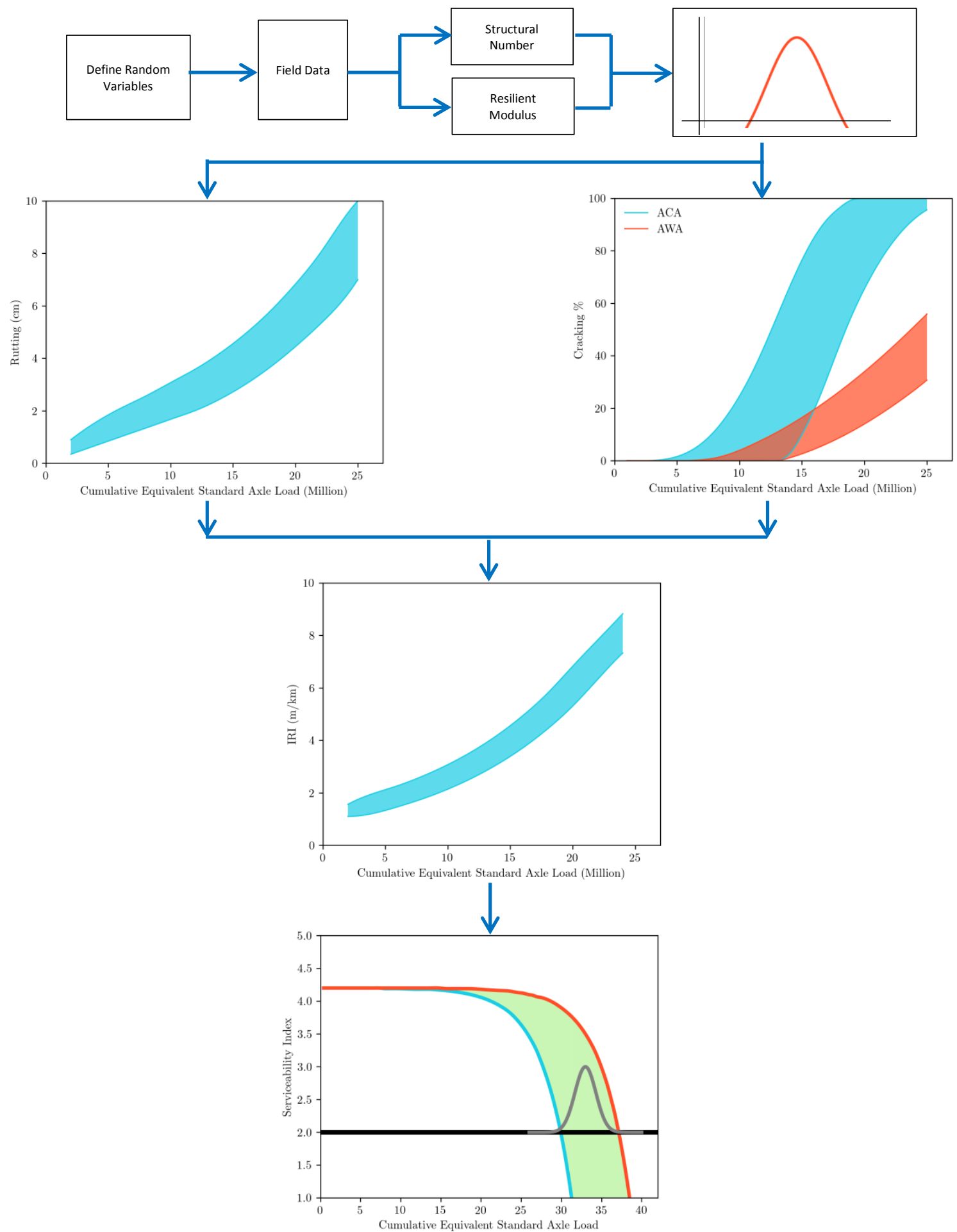


Where $\Delta \mathrm{RI}_{\mathrm{r}}$ is the incremental change of roughness due to rutting occurred during the analysis year (m/km); $\Delta \mathrm{ARDS}$ is the incremental change of the standard deviation of rutting during the analysis year - input variable $(\mathrm{mm}) ; \mathrm{k}_{\mathrm{gr}}$ is a calibration factor for the component due to rutting; $\mathrm{a}_{\mathrm{ggr}_{\mathrm{gr}}}$ is a constant of the roughness model's rutting component, provided by the model's guide.

$\Delta \mathrm{RI}_{\mathrm{e}}=\mathrm{m} \mathrm{k}_{g m} R I_{a}$

Where $\Delta \mathrm{RI}_{\mathrm{e}}$ is the incremental change of roughness due to the environment during the analysis year (IRI $\mathrm{m} / \mathrm{km}$ ); $\mathrm{k}_{\mathrm{gm}}$ is a calibration factor for the component due to the environment; $\mathrm{RI}_{\mathrm{a}}$ is the roughness at the beginning of the analysis year (IRI m/km).

The independent variables of Equation 5 are mathematical expressions calculated with the help of the cracking and rutting models estimation. The randomization of each input variable is obtained by the Monte Carlo simulation of the corresponding mathematical formulation, which generates, through a repeated execution, a set of values which are subjected to a goodness of fit test to identify the probability density function (PDF) that best represents the data of the set. Once the input variables of Equation 5 are characterized, it is possible to feed the simulation model that reproduces the IRI response; afterwards it is possible to find the probability density function that best fits the output set and represents the IRI random variable.

Once the PDF that represents the IRI is defined, it is possible to feed the PSI model through Equation 4. The PDF that characterizes the PSI variable is found through a procedure similar to that used to find the IRI PDF. The PSI value allows assessing how the pavement structure deteriorates from its implementation until its final Serviceability $P_{f}$. Since this is an incremental model, it is possible to establish the probability density function that allows evaluating the variability of the pavement's service life when the final Serviceability value $P_{f}$ has been reached. That is how the probability density function is defined, which characterizes the basic random variable of service life $f_{S}(s)$. The described procedure is performed by means of a simulation model developed with a computing tool.

\section{Definition of the Performance Function $f_{Z}(\mathbf{z})$ and the Limit State}

Once the probability density functions that represent the basic random variables of design life $f_{R}(r)$ and service life $f_{S}(s)$ have been obtained, as previously set forth, it is possible to define the random variable that describes the performance function $f_{Z}(z)$, defined through Equation 2. Thereby, by replacing the Equations that describe the design life $f_{R}(r)$ and the service life $f_{S}(s)$ in Equation 2, we find the following:

$f_{Z}(z)=9.36 \log (S N+1)-0.20+\frac{\log \left(\frac{P_{i}-P_{f}}{4.2-1.5}\right)}{0.40+\frac{1094}{(S N+1)^{5.19}}}+2.32 \log \left(M_{R}\right)-8.07-$
$\left\{5 e^{\left(-0.26\left(\left(\Delta \mathrm{RI}_{\mathrm{S}}+\Delta \mathrm{RI}_{\mathrm{C}}+\Delta \mathrm{RI}_{\mathrm{r}}\right)+\Delta \mathrm{RI}_{\mathrm{e}}\right)\right)}\right\}$

Where $S N$ is the structural number (in); $P_{i}$ is the initial serviceability; $P_{f}$ is the final serviceability; $M_{R}$ is the resilient modulus $\left(\mathrm{lb} / \mathrm{in}^{2}\right)$; and $\Delta \mathrm{RI}_{\mathrm{s}}, \Delta \mathrm{RI}_{\mathrm{c}}, \Delta \mathrm{RI}_{\mathrm{r}}, \Delta \mathrm{RI}_{\mathrm{e}}$ are the components of the roughness models explained in the previous section $(\mathrm{m} / \mathrm{km})$.

If Equation 10 becomes equal to zero, the equation that describes the limit state design is defined. A specialized software is needed to perform the reliability analysis, based on the calculation of the Hasofer-Lind's reliability index $\left(\beta_{H L}\right)$, due to the complexity of the numerical analysis of the limit state function.

\subsection{Estimation of the Reliability Index}

The PDF of the design life $f_{R}(r)$ and service life $f_{S}(s)$, are statistically uncorrelated variables and some of them have non-normal independent variables; therefore, it is necessary to use the Rosenblatt transformation to convert them into equivalent normal variables. Afterwards, the First-Order Reliability Method (FORM) can be used with specialized software to estimate the reliability index $\left(\beta_{H L}\right)$. 
The methodology mentioned above was applied on the Chilean secondary road network. The basic random functions were constructed with the Monte Carlo simulation, where the AASHTO-93 design method corresponded to the pavement design life and the deterioration model to the pavement service life. With the basic random functions defined, the performance function was found, through which a reliability analysis was performed, providing the reliability of the design for each set of roads studied.|

\section{Experimental Design}

The experimental design arranges the test section samples considering three independent variables (climate, traffic and structural number) and three statistically defined levels for each one of them (high, medium and low). The factorial matrix had 27 cells (Table 2 ).

Table 2. Factorial Design (Self-prepared).

\begin{tabular}{|c|c|c|c|c|c|c|c|c|c|c|c|c|c|c|c|c|c|c|}
\hline \multirow{2}{*}{\multicolumn{2}{|c|}{$\begin{array}{l}\text { Factors } \\
\begin{array}{l}\text { Geographic } \\
\text { Location }\end{array} \\
\end{array}$}} & \multicolumn{17}{|c|}{ Levels } \\
\hline & & \multicolumn{7}{|c|}{ North } & \multicolumn{4}{|c|}{ Center } & \multicolumn{6}{|c|}{ South } \\
\hline & Traffic & Low & & Mediur & & & $\mathrm{High}$ & & & Low & $\begin{array}{c}\text { Medi } \\
\text { um }\end{array}$ & High & Low & & $\begin{array}{c}\text { Medi } \\
\text { um }\end{array}$ & & ligh & \\
\hline Asphalt & Number & L M & $\mathrm{H} \mathrm{L}$ & $M$ & $\mathrm{H}$ & L & M & $\mathrm{H}$ & L & $M$ & $\mathrm{H} \mathrm{L} \mathrm{N} \mathrm{H}$ & $\mathrm{L} M \mathrm{H}$ & L M & H L & L M & H L & $M$ & $\mathrm{H}$ \\
\hline $\begin{array}{l}\text { Total } \\
\text { Number } \\
\text { of } \\
\text { Roads }\end{array}$ & 68 & & & 5 & 6 & & 4 & 4 & & 6 & 7 & 335 & 2 & & 11 & 2 & 6 & 4 \\
\hline $\begin{array}{l}\text { Factorial } \\
\text { sufficient } \\
\text { to carry ou }\end{array}$ & $\begin{array}{l}\text { cells with } \\
\text { information } \\
\text { ut research }\end{array}$ & & & $\sum_{\sum}^{n}$ & $\sum_{z}^{\frac{n}{E}}$ & & & I & & $\sum_{U}^{n}$ & $\sum_{U}^{n}$ & 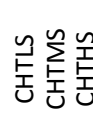 & 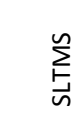 & & & $\sum_{n}^{N}$ & & 蒆 \\
\hline
\end{tabular}

Each road group was identified by three letters. The first letter representing the road group's geographical area of Chile: north (N), which is a dry and desert area; center (C), which has mild climate conditions; and south (S), the cold and rainy area of Chile. The second two letters represents the traffic level: low (LT), medium (MT) or high (HT). The next two letters represents the structural number level: low (LS), medium (MS) or high (HS). For example, NHTLS represents a road located in the North, with High Traffic and Low Structural number.

\section{Input Data}

Once the factorial matrix was defined, the objective was to find the greatest number of roads for each cell, with the purpose of obtaining higher result representativeness. Then, it was necessary to find roads constructed with flexible pavement without interventions, located in a specific climate zone and also with data of transit, structural number and resilient modulus. Additionally, they should have different ages, so that they could describe the deterioration curve in detail. The main data source was obtained from a database provided by the Ministry of Public Works of Chile (Citation) developed with field data, according to which it was possible to select information of 67 roads for 14 of the 27 cells of the factorial matrix.

\section{Performance Functions Estimation}

The data inventory of each test section was classified as variables, parameters, calibration factors and coefficients. The input variables of both models were represented as random variables by fitting a probability density function to each variable using the data taken from the database provided by the Ministry of Public Works of Chile. The values used for the parameters, calibration factors and coefficients were those recommended by the AASHTO-93 design guide in the case of $f_{R}(r)$, and by Morosiuk (1999) in the case of $f_{S}(s)$. All PDF representing the random variables, parameters, calibration factors and coefficients, can be seen in Rodríguez (2014).

In order to calculate the PDF that characterized the basic random variables of design life and service life, a simulation model was performed using the Monte Carlo method. The basic random functions that describe the design life can be found in Rodríguez et al. (2016), and the basic random functions that describe the service life can be observed in Table 3. 
Table 3. Service Life Basic Random Functions (Self-prepared).

\begin{tabular}{|c|c|c|c|c|}
\hline $\begin{array}{l}\text { Factorial Cell } \\
\text { Identification }\end{array}$ & $\begin{array}{l}\text { Type of Probability } \\
\text { Distribution Function }\end{array}$ & $\begin{array}{c}\text { Parameters of the Probability } \\
\text { Distribution Function }\end{array}$ & Mean & $\begin{array}{l}\text { Standard } \\
\text { Deviation }\end{array}$ \\
\hline \multirow[t]{2}{*}{ CHTLN } & Weibull & Shape $=3.23484$ & 15.787 & 5.3626 \\
\hline & P-Value - 0.00224136 & Scale $=17.6169$ & & \\
\hline \multirow[t]{2}{*}{ CHTMN } & Normal & Mean = 13.5815 & 13.582 & 1.9311 \\
\hline & P-Value - 0.00529752 & Standard Deviation $=1.93114$ & & \\
\hline \multirow[t]{2}{*}{ SHTMN } & Weibull & Shape $=3.67627$ & 23.957 & 7.253 \\
\hline & P-Value - 0.0197068 & Scale $=26.5556$ & & \\
\hline \multirow[t]{2}{*}{ CHTHN } & Lognormal & Mean $=49.696$ & 49.696 & 2.68331 \\
\hline & P-Value - 0.782578 & Standard Deviation $=2.68331$ & & \\
\hline \multirow[t]{2}{*}{ SHTHN } & Weibull & Shape $=4.70203$ & 31.992 & 7.7503 \\
\hline & P-Value - 0.0157797 & Scale $=34.9677$ & & \\
\hline \multirow[t]{2}{*}{ CMTLN } & Weibull & Shape $=1.99922$ & 9.8188 & 5.1343 \\
\hline & P-Value - 0.000281651 & Scale = 11.0793 & & \\
\hline \multirow[t]{2}{*}{ SMTMN } & Weibull & Shape $=8.01535$ & 12.398 & 1.8362 \\
\hline & P-Value - 0.00062051 & Scale $=13.1635$ & & \\
\hline
\end{tabular}

Once the simulation model was run and the PDF representing the design life and service life were established, it was possible to find the limit state function for the cases having enough input data available and, subsequently, the reliability analysis was performed as indicated earlier. For more information refer to Rodríguez (2014).

The probability density functions that represented the basic random variables of design life $f_{R}(r)$ and service life $f_{S}(s)$, correspond to statistically uncorrelated variables and some of them to non-normal variables; therefore, it was necessary to use the Rosenblatt transformation in order to convert them into equivalent normal variables. Afterwards, the First-Order Reliability Method (FORM) was used. The specialized software COMREL- 8 was used for calculating the Hasofer-Lind reliability index $\left(\beta_{H L}\right)$ and the failure probability ( $\mathrm{P}_{\text {Failure) }}$ for each subset of test sections of each cell of the factorial matrix (Table 2).

Results

Table 4 was obtained as a result of 1000 iterations. This table presents the reliability index ?HL, and the failure probability of the test sections classified according to the pavement configuration.

Table 4. Values of H-L Reliability Index ( $\beta_{\text {HL) }}$ and Failure Probability ( $\left.P_{\text {Failure }}\right)$ for several pavement groups located in Chile (Self-prepared)

\begin{tabular}{|c|c|c|c|}
\hline & Pavement Configuration & $\beta_{\mathrm{HL}}$ & PFailure \\
\hline \multirow[t]{2}{*}{ CHTLN: } & Roads located in the Center area, with high traffic level (954 - 6673) & & \\
\hline & and low structural number $(7.5-9.8)$ & -1.34 & 0.91 \\
\hline \multirow[t]{2}{*}{ CHTMN: } & Road located in the Center area, with high traffic level (954 - 6673) & & \\
\hline & and medium structural number $(9.8-12.7)$ & 1.93 & 0.03 \\
\hline \multirow[t]{2}{*}{ SHTMN. } & Roads located in the South area, with high traffic level (954 - 6673) & & \\
\hline & and medium structural number $(9.8-12.7)$ & -0.48 & 0.69 \\
\hline \multirow[t]{2}{*}{ CHTHN: } & Roads located in the Center area, with high traffic level (954 - 6673) & & \\
\hline & and high structural number $(12.7-16.2)$ & 5.55 & 0.00 \\
\hline \multirow[t]{2}{*}{ SHTHN: } & Roads located in the South area, with high traffic level (954 - 6673) & & \\
\hline & and high structural number $(12.7-16.2)$ & 1.36 & 0.09 \\
\hline \multirow[t]{2}{*}{ CMTLN: } & Roads located in the Center area, with medium traffic level (449 - & & \\
\hline & $954)$ and low structural number $(7.5-9.8)$ & -0.20 & 0.58 \\
\hline SMTMN: & $\begin{array}{l}\text { Roads located in the South area, with medium traffic level (449- } \\
\text { 954) and medium structural number }(9.8-12.7)\end{array}$ & 1.60 & 0.05 \\
\hline
\end{tabular}


Considering the definition of reliability mentioned above and that during the simulation of the design life, a reliability value was not taken into account:

The pavements located in the central region of Chile, with low structural capacity and medium and high traffic levels do not offer enough reliability because the failure probability obtained ranged between 0.60 and 0.90 . This means that there is a high probability that the service life will exceed the design life; therefore, the design should use high reliability values to ensure proper pavement performance.

Pavements located in the center of the country, with high traffic level and medium structural number and, in general, pavements located in the south of the country, considering the failure probability range between 0.03 and 0.09 , present enough reliability to reach the service life estimated by the design.

Regardless of the pavement's location, only high and medium traffic levels generated enough damage on the structures so as to reach the final serviceability and to be included in the reliability analysis. This indicates that pavements designed for low traffic are over-dimensioned. Finally, the same can be concluded for all the roads located in the north of the country.

\section{Conclusions}

This paper discussed the application of the reliability theory to improve de pavement life service estimation. The analytical framework is based on the integration of the AASHTO-93 pavement design method with pavement performance methods and, additionally, the variability of key independent variables used for flexible pavement design. The reliability analysis was performed using the First-Order Reliability Method implemented in the COMREL-8 software. The method allows obtaining the reliability of the pavement design based on the comparison of the pavement service life and the pavement design life, considering both variables as random variables.

The procedure described in the paper offers new considerations in terms of the current state of the practice in pavement engineering: a) the use of deterioration models calibrated with field data allows using the actual behavior of the materials, the variability of the construction process, the actual load stresses and the climate effect on pavements in service; b) the field data allow characterizing the variability of the input data using the Monte Carlo simulation to obtain probability density functions; c) the use of the reliability theory allows estimating, in a step-bystep manner, the actual reliability of the pavement design considering the variability of more input data than those used in the AASHTO-93 pavement design method; d) the integration of the reliability theory, pavement design method and pavement deterioration models enhance the reliability estimated for the pavement design.

Through a case study, the use of the tool that allowed estimating the reliability values used in the design of a group of roads was validated. In addition, it showed that the absence of an objective tool for their definition produces overdimensioned structures on site, as was the case for roads located in the north of Chile, or sub-dimensioned as it appeared in some roads located in the central zone.

The proposed method follows a robust conceptual framework, which allows obtaining reliable results. However, an improvement opportunity is to integrate all processes (variable randomization, Monte Carlo Simulation, Performance Function estimations and Reliability Index estimation) into a single pavement design tool to facilitate the pavement design task.

The variability in the constructive process of road works has not been analyzed. When behavior models are used, this variability has a significant impact on a pavement's performance. It is recommended to carry out research that can quantify this variability, in order to establish the service life estimate with less uncertainty.

This paper opens the possibility of developing new research using the proposed analytical framework, which integrates mechanistic pavement design methods and pavement deterioration models, taking into consideration that the latter must be calibrated to meet local conditions.

Acknowledgements

The first author of this publication thanks Carlos Vera-Ciro for his valuable feedback that helped improved this manuscript. The authors express their gratitude with Universidad Católica de Chile, COLCIENCIAS for funding this project and the Chilean Ministry of Public Works for sharing the data that support the results shown in this paper. 
American Association of State Highway and Transportation Officials (AASHTO). (1993). Guide for design of pavement structures. Washington, D.C.

Al-Omari, B., and Darter, M. I. (1994). Relationships between international roughness index and present serviceability rating. Transportation Research Record: Journal of the Transportation Research Board, 1435(1), 130 - 36.

Carvalho, R. and Schwartz, C. (2006). Comparisons of flexible pavement design AASHTO empirical versus NCHRP Project 1-37A mechanisticempirical. Transportation Research Record: Journal of the Transportation Research Board, 1947, 167 - 174.

De Solminihac, H., Hidalgo P. and Salgado M. (2003). Calibration of performance models for surface treatment to Chilean conditions: the HDM-4 case. Transportation Research Record: Journal of the Transportation Research Board, 1819(2), 285-293.

Dilip, D. M., and Sivakumar Babu, G. L. (2012). Methodology for pavement design reliability and back analysis using Markov chain Monte Carlo simulation. Journal of Transportation Engineering, 139(1), 65-74.

Haldar, A., and Mahadevan, S. (2000). Probability, reliability, and statistical methods in engineering design. (1st Ed.). New York: John Wiley and Sons.

Hasofer A.M., and Lind. N.C. (1974). An exact and invariant first order reliability format. Journal of Engineering Mechanical, 100, $111-121$.

Instituto Nacional de Vías (INVIAS) (2012). Manual de diseño de pavimentos. Colombia: Ministerio de Transporte.

Luo, Z., Xiao, F., and Sharma, R. (2014). Efficient reliability-based approach for mechanistic-empirical asphalt pavement design. Construction and Building Materials, 64, 157-165.

Ministerio de Obras Públicas (MOP) (2010). Estudio básico seguimiento de pavimentos asfálticos. Santiago: Ministerio de Obras Públicas de Chile.

Ministerio de Obras Públicas (MOP) (2015). Instrucciones y criterios de diseño. Volumen 3. Manual de Carreteras. Santiago: Ministerio de Obras Públicas de Chile.

Morosiuk, G., (1999). Specificactions for the HDM-4 Road Deterioration Model - Fourth, Fifth, Sixth, Seventh and Eighth Drafts. ISOHDM, United Kingdom.

Mun, S. (2014). Inversion analysis to determine design parameters for reliability assessment in pavement structures. Canadian Journal of Civil Engineering, 41(10), 845-855.

Rajbongshi, P. (2014). Reliability based cost effective design of asphalt pavements considering fatigue and rutting. International Journal of Pavement Research and Technology, 7(2), 153-158.

Rodríguez, M. (2014). Determinación de la confiabilidad implícita en el método de diseño estructural de pavimentos flexibles AASHTO-93 en base a modelos de predicción del deterioro. (Tesis doctoral inédita). Pontificia Universidad Católica de Chile, Santiago, Chile.

Rodríguez, M., Thenoux, G., and González, Á. (2016). Probabilistic assessment of asphalt pavement design. Revista Ingeniería de Construcción, 31(2), 83-90.

Rosenblatt, M. (1952). Remarks on a multivariate transformation. Annals of Mathematical Statistics, 23(3), 470-472.

Sánchez-Silva, M., Arroyo, O., Junca, M., Caro, S. and Caicedo, B. (2005). Reliability based design optimization of asphalt pavements. International Journal of Pavement Engineering, 6(4), 281 - 294.

Thyagarajan, S., Muhunthan, B., Sivaneswaran, N., and Petros, K. (2011). Efficient simulation techniques for reliability analysis of flexible pavements using the mechanistic-empirical pavement design guide. Journal of Transportation Engineering, 137(11), 796-804.

Tighe, S., Huen, K. and Haas, R. (2007). Environmental and traffic deterioration with mechanistic empirical pavement design model. Transportation Research Record: Journal of the Transportation Research Board, 1989(2), 336-343.

Videla, C., de Solminihac, H., Gaete, R. and Bustos, M. (1996). Ajuste de factores de calibración para ampliar modelos de deterioro de pavimentos asfálticos. Santiago: Ministerio de Obras Públicas de Chile. 